\title{
Hinterland Discoveries
}

\section{Middle Mesolithic Woodland Utilization and the Case of the Eidsberg Site, Eastern Norway}

\author{
Axel Mjærum
}

\begin{abstract}
Research on the Middle Mesolithic (c. $8300-6350$ cal. BC) of Scandinavia north of the Skagerrak Strait has been based mainly on data from the thousands of settlements found along the former sea, lake, and river shores. Far fewer sites have been located or investigated further away from these waters. The excavation of three Middle Mesolithic pit houses at Eidsberg in eastern Norway has therefore provided an unprecedented opportunity to gain detailed knowledge of Mesolithic activities in the hitherto under-explored forested inland. In this article, the newly discovered site and a range of other data are discussed in an ethnographical framework to understand the utilization of this hinterland as part of a semi-sedentary lifestyle.
\end{abstract}

Keywords: Stone Age; inland use; semi-sedentary; settlement pattern; pit house; hunting; Scandinavia 


\section{Introduction}

Three pit houses were unexpectedly identified and subsequently excavated in detail at Eidsberg in eastern Norway in 2015. These dwellings had been built approximately I. $3 \mathrm{~km}$ away from the ancient seashore at c. $7200 \mathrm{cal}$. BC, and even further from the nearest river or lake. The houses do not fit with the accepted model - which is empirically well-grounded and has stood for over Ioo years - that the people of the Middle Mesolithic north and east of the Skagerrak Strait lived only along the sea coast and lake and river shores.

This article will use the region's research history as a vantage point, first presenting existing data on the utilization of the forested hinterland. In the second part, the newly discovered pit house site at Eidsberg is presented as a case study with a discussion of the excavation results in an archaeological and ethnographical framework. The main aim is to gain new insight into how hunter-fisher-gatherers utilized the land between waterways as part of a semi-sedentary lifestyle during the Middle Mesolithic.

\section{The shore settlement premise}

In I900, a book was published about Danish kitchen-middens at coastal sites from the Stone Age (Madsen et al. I900) which was referred to as a work of art by Norwegian researchers (W.C. Brøgger 1905:22). Analogies were made between coast-dwelling kitchen-midden people and the Stone Age communities further north in Scandinavia (A.W. Brøgger 1905:66-67, I66). At the same time geological research was rapidly evolving, and it was considered an important task to bring greater clarity to our understanding of the isostatic rebound in the Oslo Fjord area and southern Sweden (W.C. Brøgger 1905; Munthe I9I0). In this connection surveys were prepared which showed a clear correspondence between different groups of Stone Age finds and altitude above sea level. This led to a conclusion that Mesolithic people

[...] chiefly just lived along the coast of the sea, and only to a small extent left the sea shore to follow the waterways upwards to the larger or smaller lakes, along whose shores they also found living conditions that suited them. (W.C. Brøgger 1905:I66, translated from Norwegian by the present author, italics by Brøgger, see also Sarauw \& Alin I923:67-79)

In the decades that have passed since then, several thousand Mesolithic settlements have been discovered in the former archipelago landscapes along the coast of the Skagerrak Strait in Norway and Sweden, and hundreds of them have been investigated more closely (e.g. Nordqvist 2000; Schmitt 2015; Damlien \& Solheim 20I7; Eymundsson et al. 20I8; Solheim \& Pers- 
son 20I8). Analysis of Mesolithic activity based on typology, technology and $\mathrm{CI}_{4}$ are consistent with the settlements being located on or just a few metres from the shorelines (Solheim \& Persson 2016:265-266; Breivik et al. 20I8:268).

A better overview of settlements along rivers and lakes in the forested parts of Scandinavia has also been obtained (e.g. Nordqvist 1997:40 with further ref.; Boaz I998; Glørstad 20I0:87-97; Stene 20I0; Gundersen 20I3; Eriksson et al. 20I7; Persson 20I8). These sites have largely been shown to be linked to the lake and river shores, which has led to the development of a radial model of movement along these riverine systems in the landscape of the past. As research now stands, knowledge about activity along the shores can thus be considered fairly comprehensive. However, we know far less about the utilization of the forests, and it is uncertain how, or even to what extent, the areas between waterways functioned as catchment areas in the backcountry for settlements located along coasts, rivers and lakeshores.

\section{Landscape and resources north of the Skagerrak during the Mesolithic}

A resource-rich archipelago and fjord landscape characterized the coastal environment in eastern Norway and along the Swedish west coast during the Middle Mesolithic (c. 8200-6350 cal. BC, figure I and 2), as it does today (Puschmann 2005). Behind this approximately $500 \mathrm{~km}$ coastline were large areas of relatively flat terrain dominated by vegetation of birch and pine, as well as hazel and other deciduous trees (Høeg et al. 20r8), while birch and pine also dominated the innermost areas up to altitudes of I $200-$ I300m above sea level (Selsing 20I0:8I, II5-II7 with further references). Huntable species including wild boar, red deer, roe deer and beaver lived in the temperate woodland along the coast, and elk were numerous in the boreal pine-birch zone further inland (Jonsson 1995; Hufthammer 2006; Boethius 20I7:153). The forest also offered a range of birds plus edible and useful plants, as well as an opportunity for fishing in areas where fish fauna had spread naturally after the deglaciation (cf. Mjærum \& Mansrud in press). The population in the region could thereby potentially utilize many different resources.

Physiographical conditions in the region of study thus stand out from the situation in western Norway and southern Scandinavia. The west coast of Norway is directly exposed to the North Sea, and it is characterized by deep fjords with steep sides, with much of the mainland situated at IoooI $200 \mathrm{~m}$ a.s.l. By contrast the hinterland areas in Denmark, for example, are much smaller and without large river systems. 


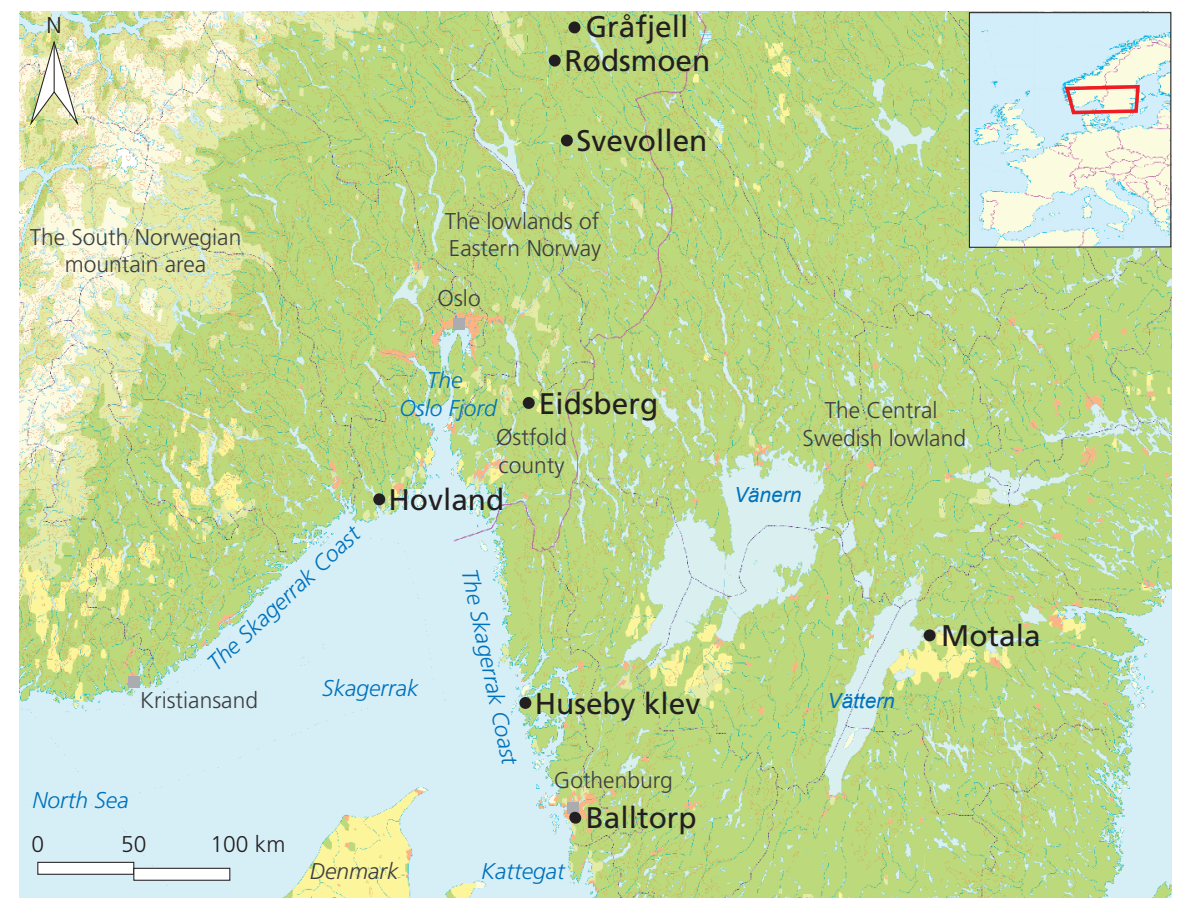

Figure I. The Skagerrak area and its northern and eastern hinterland with sites mentioned in the text. Map: Axel Mjærum, MCH.

Coast-inland relations have been discussed more comprehensively in these neighbouring areas (e.g. Olsen I992:244-256; Fischer et al. 2007; Blankholm 2008:116-II7; Bergsvik et al. 2016), but due to the differences in natural conditions these discussions cannot be transferred directly to the situation north of Skagerrak.

\section{Middle Mesolithic societies and their ethnographical parallels}

One clear trend in cross-cultural ethnographical studies of hunter-fishergatherer societies is that the importance of plant food declines as one moves farther away from the equator (Kelly 20I3:44-47). This has been explained by the fact that there is larger primary biomass production as well as a larger share of edible plants in warmer environments. In a colder climate, productivity in the oceans is higher, and fish and marine mammals in general replace parts of the plant food (Kelly 20I3:44-47 with further references). In addition, there is a tendency towards an increased spatial concentration of fish, sea mammals, birds and ungulates in temperate and cold environments. 
A consequence of these environmental differences is that hunter-fishergatherers in northern environments often reside in ecological hotspots. In such cold environments the practice of storing and sharing food is widespread, which often leads to lower residential mobility (Binford I980:I4I6). A major part of hunter-fisher-gatherer societies in the northern regions can thus be categorized as collectors: a type of society with few or no residential moves, but where task groups may leave a residential location and establish different types of field camps as temporary centres for their activities and as places for storage, as well as stations from which food-procurement operations may be planned and executed (cf. Binford I980:IO-I2).

The first known permanent dwellings appear along the coast in eastern Norway and the west coast of Sweden c. 7500 cal. BC (Hernek 2005; Fretheim 20I7), and it has been argued that from this point onwards ecological hotspots played a significant role as bases for the systematic and varied utilization of a wide range of marine resources (e.g. Mansrud \& Persson 2018; Solheim \& Persson 2016; Mjærum \& Mansrud in press). The sea also provided central water-based routes facilitating the utilization of a wide range of resources found in other parts of the landscape, and the thousands of smaller sites along the Skagerrak coast are interpreted as traces of task groups exploiting a wide range of resources (e.g. Bjerck 2008; Solheim \& Persson 20I8).

In the inland zone north of Skagerrak some lacustrine areas had much of the same potential, with rich opportunities for harvesting a wide range of resources including big game, fish and birds (Mjærum \& Mansrud in press). Numerous smaller sites support the idea that the hunter-fisher-gatherers in the inland similarly supported themselves with resources from their habitation areas as well as specially organized task groups who visited other parts of the terrain.

During the Middle Mesolithic the use of the hinterland is thereby a question of exploitation either directly from the residential camp, or if there was extensive utilization of the forests, by task groups as part of longer trips. Information about the specific use of the hinterland in the northern Skagerrak area can potentially be gained by looking in more detail at parts of the general archaeological record from the forested areas.

\section{The shorebound settlement model and its nuances}

Frequent discoveries of lithic material, charcoal and hazelnut shells at the seashore sites reveal that land resources were important even in the coastal zone. There are also elements of smaller terrestrial species in the limited cre- 
mated bone material from these settlements, even though the assemblages from coastal areas are dominated by fish, marine mammals and seabirds (figure 9; cf. Glørstad 20I0:80-84; Mansrud 20I4:84-86; Boethius 20I8). At the Middle Mesolithic settlements of Balltorp and Huseby Klev near Göteborg, for example, a small number of elk and auroch bones have been identified, as well as other ungulates (Boethius 2017:15I, 2018:106). Fish were also a significant part of the diet inland (Boethius \& Ahlström 20I8; Mjærum \& Mansrud in press). Nevertheless, there is a high proportion of forest animals such as elk and beaver among inland finds north and east of the Skagerrak coast (see figure 9).

In recent years isotopic analysis of human bones has also provided new and important information on the balance of marine and terrestrial diets. This research has stimulated and formed the basis for renewed discussion of the Middle Mesolithic settlement pattern. Isotopic analysis of the limited quantity of human osteological remains from the archipelago north and east of Skagerrak indicates that the diet there was largely based on resources that were possible to locate near the settlements, implying low mobility (Lidén et al. 2004; Skar et al. 2016; Boethius \& Ahlström 2018). However, analyses of an individual from the inland area in western Sweden show a change of diet from a marine to a terrestrial diet during life (Lidén et al. 2004:28; see however Boethius \& Ahlström 20I8:207 for a criticism of this interpretation). Isotopic measurements of I4 of the Late Mesolithic individuals from Motala at the outlet of Lake Vättern in eastern Sweden reveal a similar complexity (Eriksson et al. 20I7). Overall these analyses show great variation in the balance of marine and terrestrial diet between individuals and between different groups. The results from Motala indicate that even within one cultural setting, different choices could be made, and many opportunities arose which contributed to shaping an individual's intake, but also that people tended to make different choices in similar situations (cf. Grøn 20I2). Consequently, a large variation must be expected.

Various ethnographic studies show that it is not uncommon for hunters in uneven terrain to traverse $20-30 \mathrm{~km}$ per day without much effort (Kelly 2013:97). Often hunting, fishing and collecting were also conducted $5 \mathrm{~km}$ or more from the camps. Abundant and varied woodland resources could therefore be reached from the settlements along the shores. Pollen analyses corroborate that there was activity in areas of land that were several hundred metres, and maybe even several kilometres behind the coastal zone (Wieckowska-Lüth et al. 20I8). Occasionally, however, the best option may have been to organize task groups which went into the hinterland for a shorter period of time, in the same way as numerous short-term sites were established along the shores. 
Due to the research history of the region, archaeologists have mainly focused survey work on former shores, with the likely consequence that hinterland sites are underrepresented for methodological reasons (cf. Bjørgo I988:21 8-222; Indrelid I994; Berg-Hansen 2009). However, there are in fact archaeological data which support the idea of activity by task groups at a greater distance from past sea shores, lakes and rivers. In an earlier review of the known settlements on the eastern side of the Oslo Fjord, Inge Lindblom (1984:64, 67-68) highlighted finds of Middle Mesolithic material one kilometre from the ancient course of the Glomma, while other sites which lay high up in the terrain may potentially be linked to Middle and Late Mesolithic hinterland activity (see figure 2). Further inland, Late Mesolithic/Early Neolithic pit houses have been excavated in pine forest terrain at Svevollen (Fuglestvedt 1992) and Rødsmoen (Boaz I997; Persson 2013). Both these dwelling sites are located in forested zones along streams, approximately $2 \mathrm{~km}$ from the nearest large river. They were clearly established to target resources in the woodlands, especially elk (see figure 9).

Anincreased occurrence of charcoal has been documented in the Mesolithic strata of some pollen diagrams from the interior lowlands and is interpreted as a consequence of human influence (e.g. Høeg I997:I27; see WieckowskaLüth et al. 2018 with further ref. for a discussion of this interpretation). Another example of hinterland utilization is from Gråfjell, approximately $250 \mathrm{~km}$ from the sea (figure I), where several small Stone Age settlements and independently situated cooking pits dated to the Mesolithic have been found several kilometres from the major waterways (Amundsen 2007). In addition, there are some finds from the Mesolithic located far away from the major watercourses in the lowlands. One of the best-known examples is an elk antler mattock head from eastern Toten in Oppland (Mikkelsen \& Høeg I977:I3-I4), but there are also several other such finds in the area (see e.g. C27864, C29194, $\mathrm{C}_{32854}$, $\mathrm{C}_{56218}$ and $\mathrm{C}_{5} 6985$ in Unimus 2018).

Stone quarries should also be mentioned in this context. Some are located on higher ground, often at some distance from the past shoreline (Nyland 20I6). In addition, lithic raw materials have been shown to be distributed transversely in relation to waterways (e.g. Kindgren I991; Stene et al. 20I0:500-508; Gundersen 20I3:52-54; Nyland 20I6), substantiating the use of areas between waterways as thoroughfares.

The overall impression is that that people occasionally chose to move into the hinterland to hunt, gather and also to procure stone, and all the while the population used the hinterland as a route of travel. Until the discovery of the pit house site at Eidsberg, however, there were no excavations of sites in the region which could provide detailed information about the use of the region's hinterland in the Mesolithic. 


\section{The Eidsberg pit house site}

\section{THE STONE AGE LANDSCAPE OF ØSTFOLD}

Østfold was centrally located in the area of the Skagerrak coastal landscape under discussion. In the middle part of the Middle Mesolithic (c. 7200 BC) the sea was about $75 \mathrm{~m}$ higher than today in the north of Østfold (R. Sørensen 2006:46), with fjords that stretched as far as Io to $20 \mathrm{~km}$ inland. Outside there was a wide belt of small and large islands (see figure 2).

The central part of Østfold was framed by the waterway Haldenvassdraget in the east and to the west Lake Øyeren, the now-disappeared Glomma Fjord, and a length of river (figure 2). The landscape enveloped by these features was partly characterized by wooded clay flats and V-shaped ravines, and partly by a terrain of rounded hills (see Puschmann 2005). The moraine deposit known as the Mona Ridge appeared as one of the most marked features between the two water systems, lying like an island with sandy areas (Nyborg 2009:I20). Formed by thick moraine and surrounded by beach deposits, the ridge is $3-4 \mathrm{~km}$ long, up to $60 \mathrm{~m}$ high and about $\mathrm{Ikm}$ wide. The north side of the formation is steep, while the front has a gentler profile. Several wellsprings have their origin at the foot of the moraine deposit, ensuring a supply of water (Båtvik 2000:I2I).

The wellsprings and brooks have cut down into the edge of the sandy areas and into the clay ground between the Mona Ridge and the Glomma Fjord. The formation of this ravine landscape began as soon as the sea disappeared from the area, so that the valleys were already a central landscape element during the Mesolithic. There are no pollen analyses to provide detailed information about the vegetation on the ridge in the Stone Age, but at present the ravine landscape is a lush habitat with highly varied vegetation (Båtvik 2000:I2I). Pine must have been an important part of the forest on the sand and gravel ridge in Mesolithic times, with the species still growing to great diameters and heights in the area (Christensen 20I4:8; cf. see Danielsen 1970:9I-96). Undergrowth is often limited in fully grown pine forest (Rekdal 20I8), and along with the gently sloping landscape, this must have created quite different natural conditions from the ravines to the south. It is very likely that the Mona Ridge provided living conditions for elk, which were otherwise rare in the coastal hinterland in the Middle Mesolithic (cf. Jonsson 1995:150; Boethius 2017:153; see also below).

The southern slope of the Mona Ridge was reached by humans by 7200 BC. The place was then about $85 \mathrm{~m}$ above sea level and about $\mathrm{I} .3 \mathrm{~km}$ from the past coastline. Hunter-gatherers established a habitation on the edge of the moraine, respectively about $50 \mathrm{~m}$ and $\mathrm{I} 5 \mathrm{Om}$ west of two springs with gentle flows of water. Consequently, from this habitation area it was only a short way to the lush and hilly ravine landscape, while at the same time 


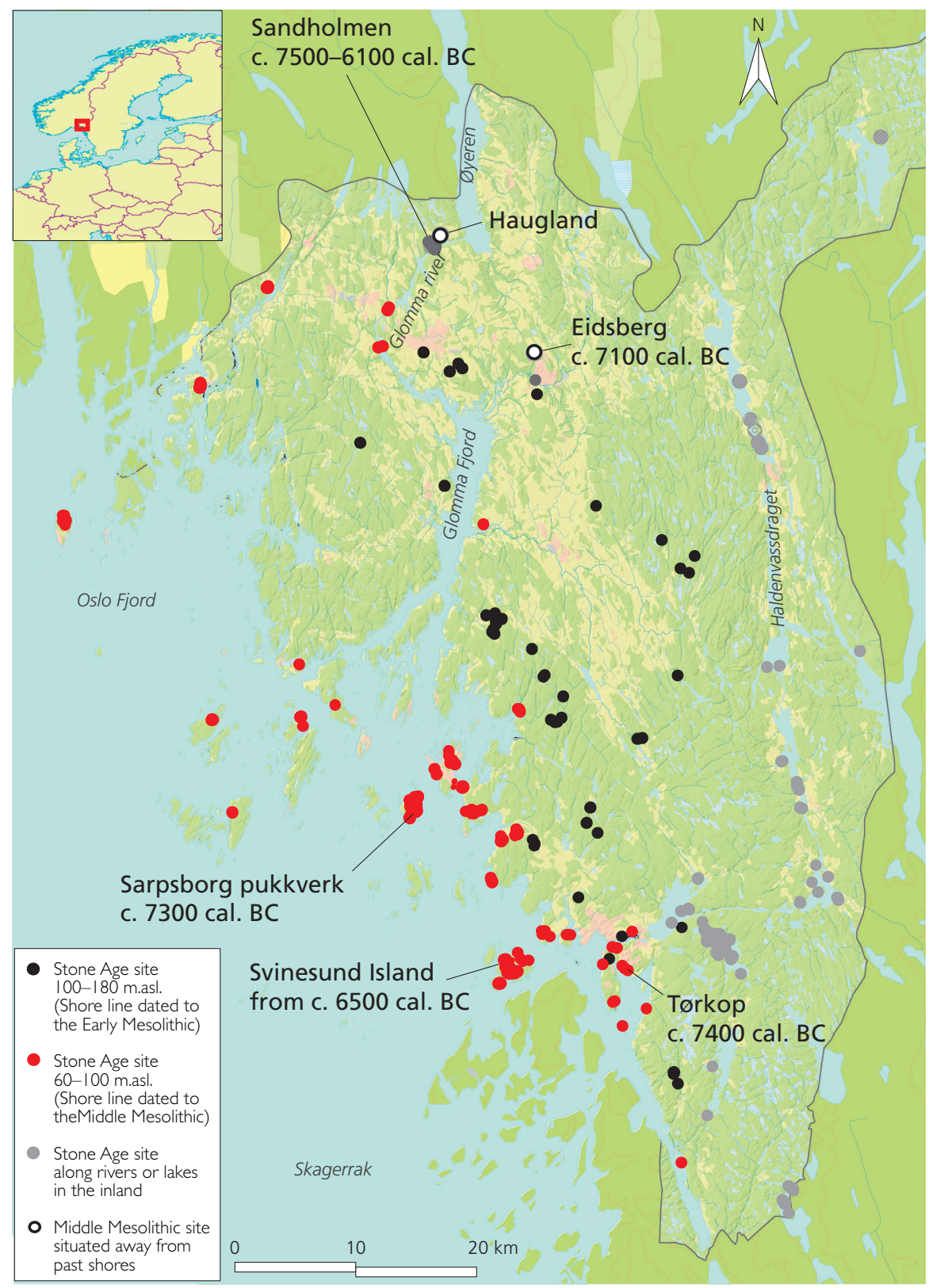

Figure 2. The palaeo-landscape of Østfold county c. 7500 cal. BC with known Middle Mesolithic sites. Map: Axel Mjærum, MCH.

the pit houses were located in the open pine forest on the Mona Ridge. It was in this border area that an excavation was carried out in 2016 (Mjærum 20I8a). 


\section{THE PIT HOUSES}

The settlement itself was located in a field and was investigated in in advance of construction. Ploughing had led to the loss of around $30 \mathrm{~cm}$ from the top of the building remains. Below this level, however, were floor surfaces with preserved inhabitation layers and objects.

The three buildings lay 7.5-Iom apart. Both the dispersion of objects and the cultural layers indicated that the dwellings were oval and had a floor area of approx. $6 \times 5 \mathrm{~m}$ (see figure $3-5$ ). The floor layers were generally 0.15-0.3 $\mathrm{m}$ thick, but because the area had been ploughed it can be assumed that the recesses were once dug down to about twice that depth. Once the plough soil was removed by excavator, the culture layers were unearthed manually in their entirety and excavated material was watersieved through 2 and $4 \mathrm{~mm}$ mesh. All lithic material, nutshells and bones were collected from the excavated parts of intact cultural layers. Plough soil and depressions caused by uprooted trees were sieved to a limited extent. The floor layers were shown to contain small pieces of charcoal and humic substances (Macphail \& Linderholm 20I7).

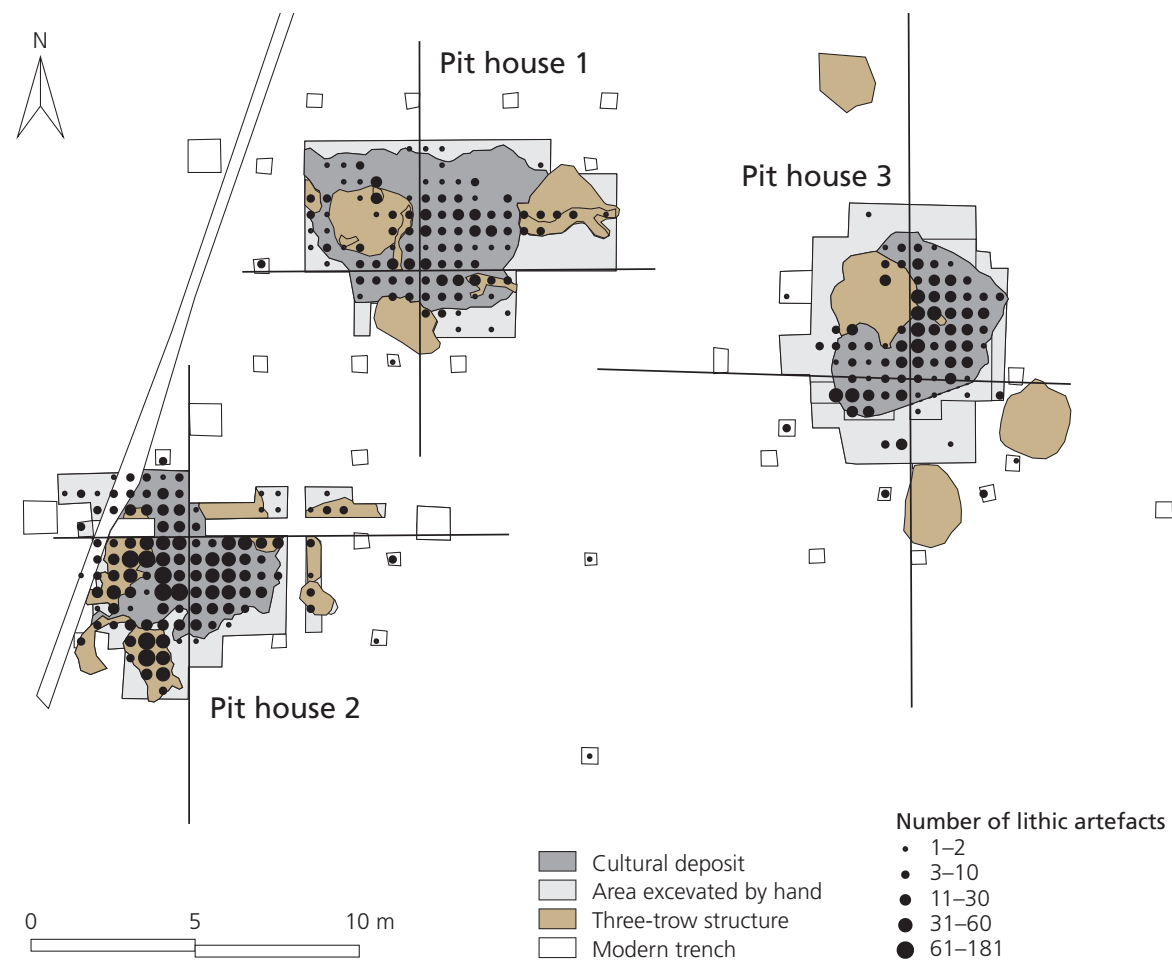

Figure 3. The three houses at Eidsberg with the distribution of lithic artefacts. Map: Axel Mjærum, MCH. 


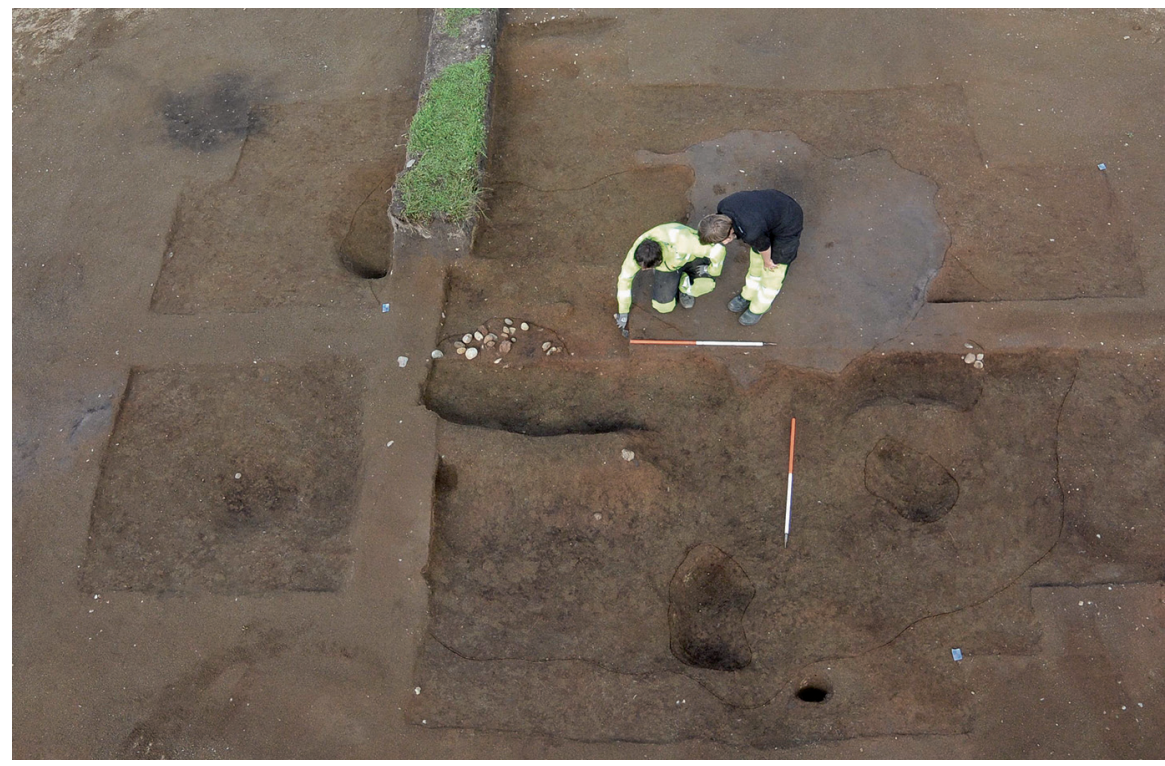

Figure 4. Pit house 3. The majority of the cultural deposits have been removed. A partly excavated hearth is seen in front of the archaeologists who are standing on a filled depression caused by an overturned tree trunk. Axel Mjærum, MCH.

Distinct postholes did not appear either inside or outside the floor area. On the other hand, we documented five smaller pits and some stones at the circumference of the floor areas in pit houses 2 and 3 . It is possible that these elements represent a form of wall construction. In pit house 3 there were also two construction features which are not easily explained. In the southwest part, we found a I.7m wide pit which had been dug down $0.25 \mathrm{~m}$ below the floor level. In addition, the floor area of this building was divided into two by a $0.5 \mathrm{~m}$ wide and $4.2 \mathrm{~m}$ long bench of subsoil. The earthen bench may perhaps best be understood as a form of inner wall. Fireplaces appeared in the southern part of two of the buildings, and a collection of cremated bones indicates that there was also a fireplace in the southern part of the third pit house.

Based on the results of the fieldwork, the buildings can easily be categorized as pit houses with a very uniform appearance. No wall mounds were found in the form of ramparts, nor was this expected in a place where the plough would have removed such low elevations in the terrain. An absence of roof-supporting posts may be an indication that the roof was constructed of lighter materials, perhaps of branches or hides. Both of the preserved fireplaces lay partly over cultural deposits (figure 5), while traces of older phases of fireplaces were absent. This feature can be explained by the fact that the fireplace was established on a floor surface, and consequently the 
lower parts of the cultural layer are not formed of waste but of floor material (cf. Grøn 2003; Hernek 2005:I88-205). Since objects were deposited down to the bottom of the culture layer, one can assume that the floor was not closed but formed from branches, straw and the like. Objects could thus have found their way through the floor cover.

Neither the traces of the building construction nor the distribution of artefacts provide any information about the location or design of the entrance. Hardly any fired and cracked stones or objects were found around

Eidsberg fengsel, Eidsberg, Østfold

Pit house 3, cross section 3354



Hut 3, cross section 3633

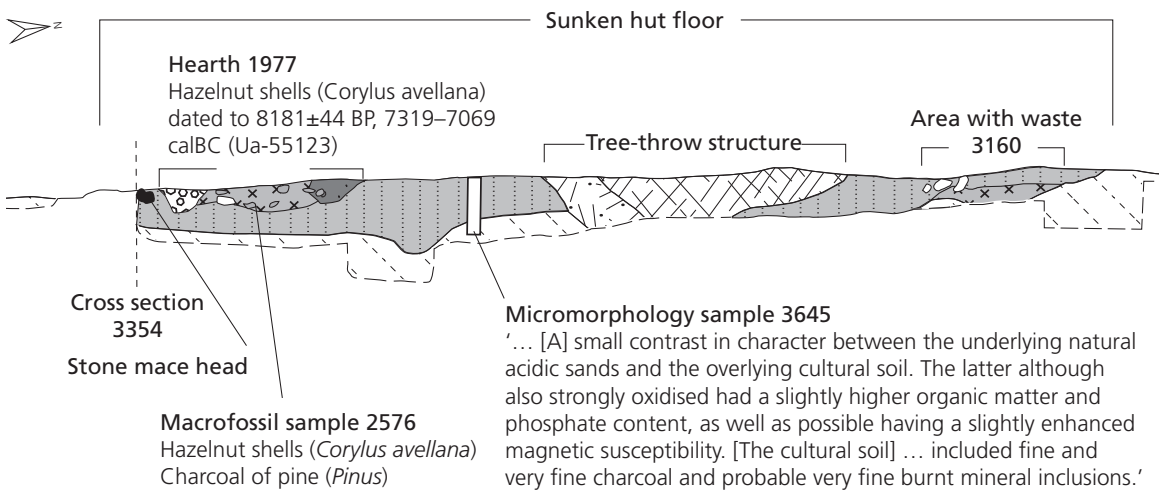

\footnotetext{
Bleached, gray brown sand with humus (cultural layer)

Brown black fine grained sand with some charcoal (hearth)

Red, heat affected sand (hearth)

Pod Coarse, red yellow sand with some humus (part of hearth)
}

7. X Heterogeneous sand with humus and former vegetation layers (tree-throw structure)

$\square$ Coarse, red sand (sub-soil)

$\triangle$ Dark brown sand with humus (plough-soil)

o/ o Stone / heat affected stone

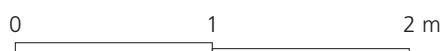

Figure 5. Cross-section through pit house 3 with the results of the analysis. Drawing: Axel Mjærum, MCH. 
Table I. Key data from the three pit houses at Eidsberg.

\begin{tabular}{|c|c|c|c|c|c|c|c|c|}
\hline $\begin{array}{l}\text { Pit } \\
\text { house }\end{array}$ & $\begin{array}{l}\text { Area } \\
\left(\mathrm{m}^{2}\right)\end{array}$ & $\begin{array}{l}\text { Lithic } \\
\text { artefacts }\end{array}$ & $\begin{array}{l}\text { Cremated } \\
\text { bones }(\mathrm{g})\end{array}$ & $\begin{array}{l}\text { Hazelnut } \\
\text { shells }(g)\end{array}$ & C14 dated material & Lab.no. & $\begin{array}{l}\text { Dating } \\
\text { uncal. BP }\end{array}$ & $\begin{array}{l}\text { Cal. BC } 2 \Sigma \\
(95.4 \% \\
\text { probability) }\end{array}$ \\
\hline \multirow[t]{4}{*}{1} & $<27.4$ & 565 & 29.8 & 5.8 & $\begin{array}{l}\text { Marine or terrestrial } \\
\text { mammal }\end{array}$ & Ua-55053 & $8303 \pm 39$ & $7487-7191$ \\
\hline & & & & & $\begin{array}{l}\text { Marine or terrestrial } \\
\text { mammal }\end{array}$ & Ua-55052 & $8001 \pm 33$ & $7058-6779$ \\
\hline & & & & & Hazelnut shell & Ua-55120 & $8179 \pm 44$ & 7317-7068 \\
\hline & & & & & Hazelnut shell & Ua-55119 & $7893 \pm 37$ & $7024-6644$ \\
\hline \multirow[t]{5}{*}{2} & 18.9 & 2481 & 46.9 & 13.4 & Terrestrial mammal & Ua-55055 & $8306 \pm 34$ & 7488-7194 \\
\hline & & & & & $\begin{array}{l}2 \text { fragments large } \\
\text { terrestrial mammal }\end{array}$ & Ua-55056 & $8283 \pm 38$ & $7468-7187$ \\
\hline & & & & & Hazelnut shell & Ua-55121 & $8202 \pm 44$ & $7339-7075$ \\
\hline & & & & & Hazelnut shell & Ua-55122 & $7980 \pm 43$ & $7051-6701$ \\
\hline & & & & & Large ungulate & Ua-55054 & $7379 \pm 34$ & 6377-6104 \\
\hline \multirow[t]{4}{*}{3} & 20.2 & 959 & 51.3 & 55.5 & $\begin{array}{l}\text { Medium-sized } \\
\text { mammal }\end{array}$ & Ua-55058 & $8321 \pm 34$ & $7506-7206$ \\
\hline & & & & & $\begin{array}{l}\text { Large terrestrial } \\
\text { mammal }\end{array}$ & Ua-55057 & $8319 \pm 35$ & $7505-7201$ \\
\hline & & & & & Hazelnut shell & Ua-55123 & $8181 \pm 44$ & 7319-7069 \\
\hline & & & & & Hazelnut shell & Ua-55124 & $8140 \pm 44$ & $7302-7050$ \\
\hline $\begin{array}{l}\text { Other } \\
\text { contexts }\end{array}$ & & 98 & - & - & & & & \\
\hline Total & & 4103 & 127.6 & 74.7 & & & & \\
\hline
\end{tabular}

the pit houses, nor were fireplaces or other structures located in their surroundings. Consequently, there are no traces of outdoor activities. It is difficult to determine to what extent ploughing has removed such traces, but it may be that the site never contained large amounts of fire-cracked stones used for heating. The absence of stone middens is important since such features have commonly been interpreted as evidence of winter occupation (Boaz 1996; Lundberg 1997; Fretheim 2017:36).

\section{THE SCOPE OF ACTIVITY AND THE TIME OF USE}

In total, 4IO3 stone objects were found during the excavation, largely in connection with the three houses (see figure 3 and table I). It seems clear that there was significantly less activity at Eidsberg than at the largest archipelago locations from the Middle Mesolithic (e.g. Mikkelsen et al. I999; Solheim \& Olsen 2013), coastal sites which should probably be seen as longterm residential settlements. Yet the amount of finds, and presumably thus also the scope of activity at Eidsberg, is significantly greater than at the many small sites in the region, places which were only visited briefly one 
or a few times (e.g. Solheim \& Damlien 2013; Solheim 20I7), and which are often interpreted as stations established to carry out specific tasks. In this way the lithics from Eidsberg take their place in an upper intermediate level in terms of the number of artefacts and the expected range of activity. It is undeniable that the activity was extensive, but it was probably not long-term or year-round (see below). The site can thereby be interpreted as a field camp in Lewis Binford's (I980) sense of the term.

The lithic artefacts form one of several possible starting points to answer the question of whether the buildings were in use at the same time, even though no effort has been made to refit artefacts at the site. Among the best chronological markers is a mace head which appeared in the culture layer in pit house 3 . An almost identical object was found at the excavation of Hovland I in Larvik, Vestfold, a settlement dated to c. 7500 BC (Olsen 20I3). A number of similar types of mace heads have been dated to the period 7700-7000 BC. (Mikkelsen et al. I999; Solheim \& Olsen 2013:207208; Persson 20I4:2I6; Carrasco \& Mjærum 20I5), and the object thus contributes to the establishment of a rough timeframe for the activity at the settlement. We also found two edges of ground axes in volcanic raw materials, and probably at least one of them is a pecked and ground axe. These were in production before $7500 \mathrm{cal}$. BC, but they make up a more significant share of material found after that time (Eymundsson et al. 20I8).

The proportion of blades and microblades is $\mathrm{I} 3.5 \%$, which is among the highest known in the Oslo Fjord area (see figure 6; cf. Glørstad 2004:45; Reitan 2016:32-36; Solheim \& Damlien 20I6; Solheim 2017). In addition, a substantial part of the remaining waste material is semi-conical cores and other debris associated with blade and microblade production. Accordingly, the main objective of the flint knapping was to produce narrow, elongated and thin flint pieces. Such purposeful blade and microblade technology based on semi-conical cores is a primary characteristic of the lithic toolmaking of the Middle Mesolithic in this region (c. 8300-6350 cal. BC, Eigeland 2015:373-374; Damlien 2016; Reitan 2016:3 I-33). Indirect dating of the activity to the period $7700-7000 \mathrm{cal}$. BC therefore seems reasonable from the perspective of the stone tool technology.

The width distribution of the blade material changes over time north of the Skagerrak coast, in line with related technological changes (see M. Sørensen 2006; Damlien 2016:34I-343; Reitan 20I6). The width of the objects also varies considerably from site to site, which may be related to factors ranging from raw material access, to which production steps are represented, to the skills of the knapper, personal preferences, or how the objects were used (Eigeland 2015). The almost identical variation in the width of blades and microblades in the three houses at Eidsberg, and a clear deviation from other sites (see figure 6), can therefore be attributed to 


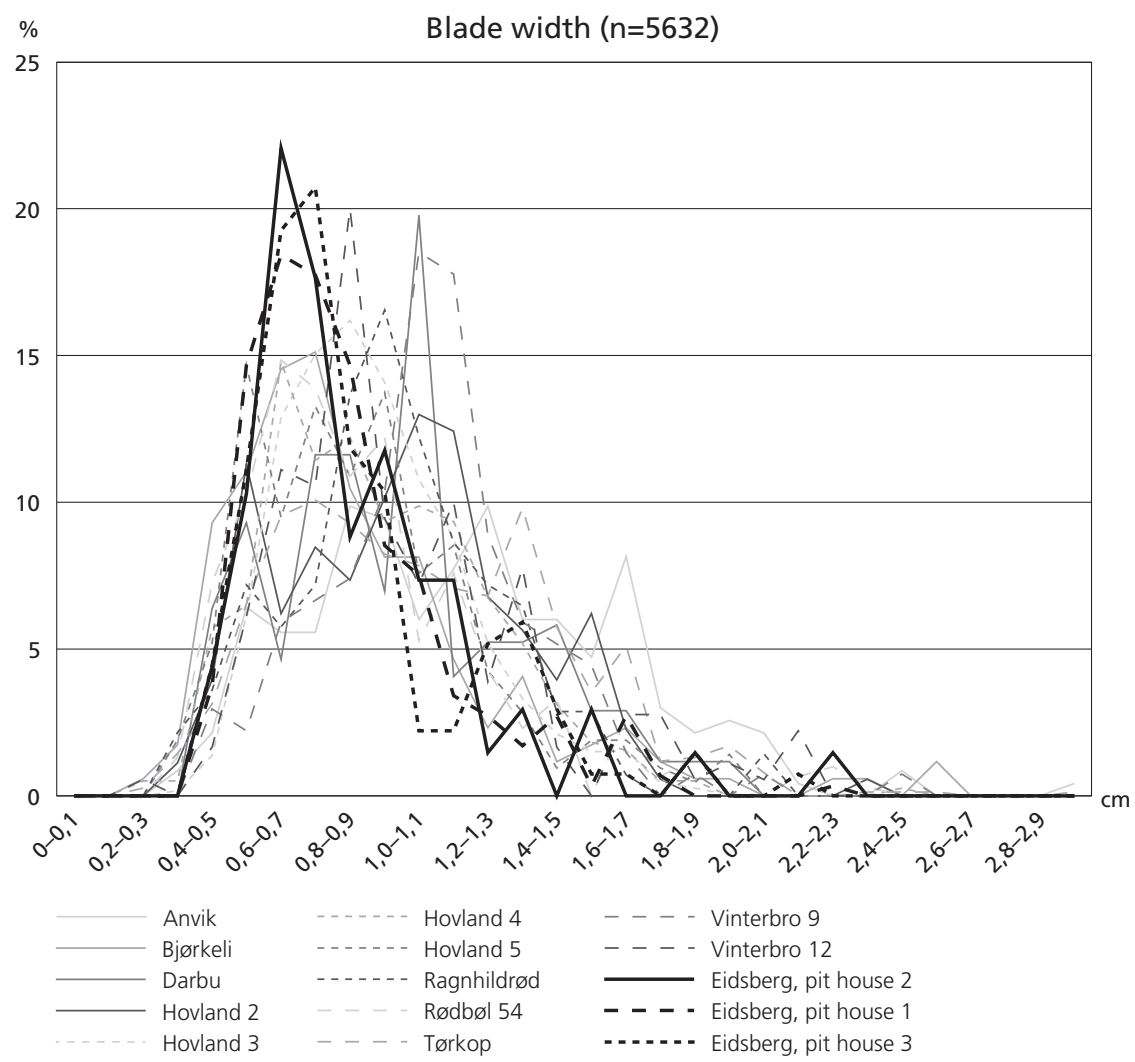

Figure 6. The width of blades from the dwellings at Eidsberg, compared with similar measurements from I 2 other Middle Mesolithic sites (based on data from Damlien 2016 and Solheim \& Damlien 20I3).

the fact that they were produced within the same tradition, and even most likely during the same visits.

To obtain more knowledge about the dating of the three pit houses and the temporal relationships between them, $\mathrm{I} 3$ samples of hazelnut shell and cremated bone were tested using the radiocarbon method. All the houses had very similar dates for the initial activity, with the oldest dates on bone c. $7500-7200 \mathrm{cal}$. BC and nutshells dated to c. 7300-7100 cal. BC (table $\mathrm{I}$ and figure 7). In cases in which old wood was used as fuel when bones were cremated, an offset of decades and even centuries can occur (Olsen et al. 20I3; Snoeck et al. 20I4), so nutshells were considered most suitable for dating the onset of activity at the settlement. The analysis also indicated activity in the centuries around $7000 \mathrm{cal}$. BC. In addition, a date in the timespan of 6377-6104 cal. BC has also been established for the bone from an ungulate from pit house 2 ; this outlier is not in line with the other information from the site and is thus hard to explain. 
OxCal v4.3.2 Bronk Ramsey (2017); r:5 IntCal13 atmospheric curve (Reimer et al 2013)

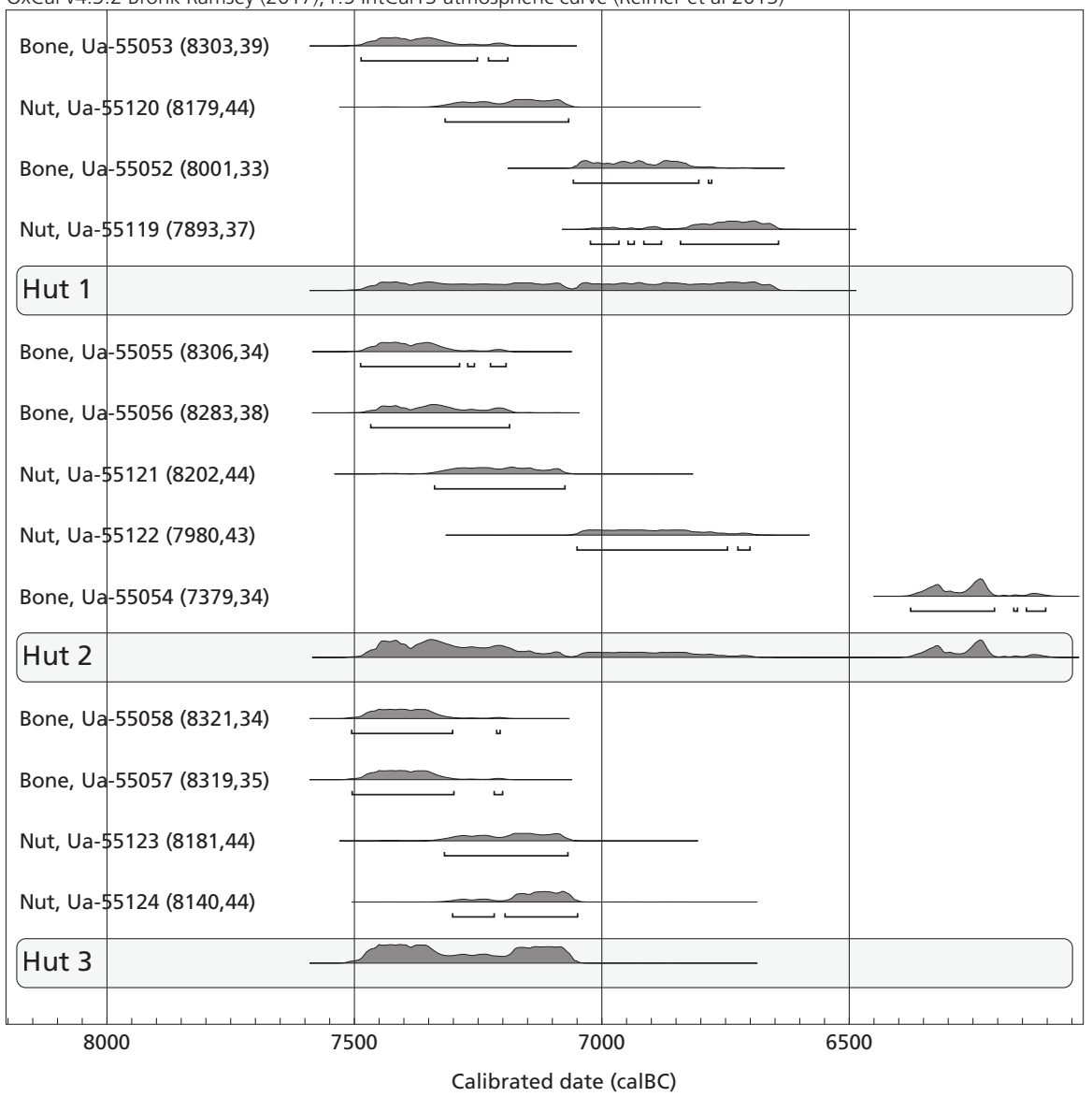

Figure 7. Radiocarbon dates from the pit houses at Eidsberg (see also table I).

Based on the dates, the uniform building tradition, and the similarities in the inventory of finds, it can be stated without doubt that the buildings must be seen as one context. The dwellings are, as already mentioned, spaced only 7.5-Iom apart, which provides a further basis for interpreting the dwellings as traces of simultaneous stays. Based on the ecofacts from the three houses, the inhabitants evidently produced hunting equipment, hunted small and big game (figure 9), and collected hazelnuts and fuel. Accordingly, the site can be seen as a field camp where the buildings were linked to separate households. Such an organization enabled the visitors not only to hunt, but also to perform a wide range of other work tasks (see Grøn 1995; Glørstad 2010:152-160). Such tasks can be carried out by a mixed group of adults and children, which provides grounds for believing that it was family groups who sought out the Mona Ridge. 


\section{WHERE DID THEY COME FROM?}

Ice and ocean currents transported flint from southern Scandinavia to the beaches of the past (Eigeland 2015:45-53). Locally available beach flint resources were utilized as raw material during the Middle Mesolithic, probably combined with imports from the Swedish southwest coast or Denmark (Eigeland 2015:367). Quartz and quartzite can be found locally and were used for blades, microblades and other small artefacts in the coastal zone of the Middle Mesolithic. In most cases, however, such material is only represented by a few items at sites along the past seashores in northern Skagerrak (Eigeland 20I5:37I-372). Inland, the use of quartz and quartzite was generally far higher, and sometimes these locally available raw materials are dominant (e.g. Indrelid I994:275-282; Mikkelsen 1989:79-82; Solheim 20I0:34-36, 20I 2:2I3-2I9). Inland localities with a high share of flint have therefore been explained by a close connection with the coastal areas (e.g. Mikkelsen I989:85; Solheim 20I2:228). At the same time, use of raw materials has been linked to how familiar people were with the resources of the inland environment, and whether they had acquired knowledge of the properties of the local lithics (e.g. Mikkelsen I989:82; Solheim 20I 2:227). Differences in the use of a raw material are also related to a tradition-driven practice (e.g. Pelegrin 1990), and the significance that was ascribed to local and more exotic stone materials (Bergsvik 2006:154; Eigeland 2015:368$372,386)$. Accordingly, the use of lithics must be understood as a result of resource access, communication and cultural preferences. Of the objects found in the Eidsberg house pits, $92.3 \%$ were of flint, while 7.I\% were of quartz. Thus, the content of quartz as a raw material is higher than at most coastal sites, but lower than normally found in inland settlements. Accordingly, access to flint was relatively good, thus linking the activity at Eidsberg to the skerry coast and fjord further south.

It appears that the quartz-working at Middle and Late Mesolithic locations in the Oslo Fjord area was carried out on high-quality cores that arrived at the sites already shaped (Eigeland 2015:37I). Such a strategy does not fully fit with the lithics from Eidsberg. High-quality quartz is indeed found in the inventory, but a substantial part of the quartz material from Eidsberg is coarse-grained and of poor knapping quality. Some of the cores were discarded after initial quality testing. It is tempting to understand this utilization pattern as a result of the source of the raw materials being in the immediate area (cf. Pelegrin 1990; Inizan et al. 1999; Eigeland 2015).

Of the quartz material, $2.7 \%$ (8 pieces) consist of blades and microblades. The presence of these objects, combined with one semi-conical core, shows that raw quartz was used for microblade production using the same technology as for the flint raw materials (cf. Eigeland 2015:37I-372). How- 




Figure 8. Fragments of quartz and flint glued together with resin. Notice the imprint of a slotted bone implement at the left side of the resin. The fragment is $\mathrm{I} . \mathrm{I} \mathrm{cm}$ in length. Photo: Axel Mjærum, MCH.

ever, the discovery of flakes and flake cores is as prominent a feature of the quartz material, and consequently the technology was clearly adapted to fit this coarser raw material. That flint and quartz then mutually complemented each other and were combined in the same technology is shown by a small resin piece with an attached quartz piece and flint which appeared in connection with house pit 2 (figure 9). This composite item also has a mark from being inserted into a slot; it is most likely part of a slotted bone point. In the coastal areas such inserts were almost exclusively made of flint, while a considerable proportion of the points in the interior have quartz and quartzite inserts (Damlien 20I4:IO). Further to the east on the Scandina-

Figure 9. The species identified in the material of cremated bones to a large extent reflect hunting, fishing and trapping in the environments surrounding the sites. Top: Identified species/groups at the Eidsberg site (NISP=76). An additional 938 identified bones from mammals and 28 unidentified bones were retrieved from the site. Identification by Rudolf Gustavsson (20I6). Bottom left: Identified and counted bones from I4 selected Mesolithic sites from the coastal zone of eastern Norway (NISP=I378, Mikkelsen et al. I999; Jaksland 200I:I00; Glørstad 20I0:72, 79; Eymundsson 20I2; Ekstrand 20I3; Melvold \& Eigeland 2OI4:246; Mjærum 20I9). Bottom right: Identified and counted bones from I5 selected Mesolithic sites from the inland of eastern Norway (Hufthammer \& Hodgetts 1997:I50; Stene et al. 20I0:488; Melvold 20I2; Winther \& Persson 20I6). 
Marine mammal; 2 Terrestrial mammal; 2 Ruminant; 1

Small mammal; 7



Medium sized mammal; 24

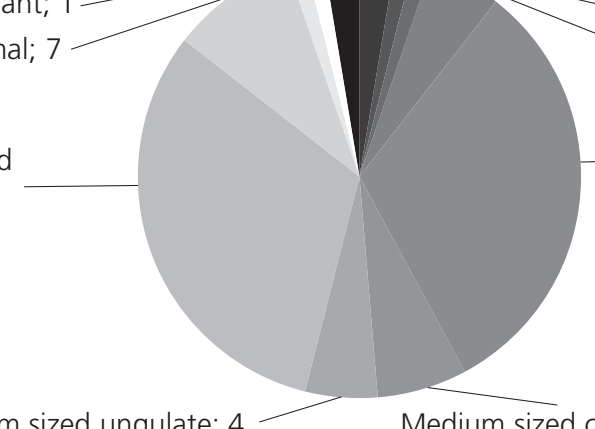

Seal (Phocidae); 2 Beaver? (Castor fiber?); 1 - Bird of pray; 1 Large ungulate; 4 Large mammal; 24

The Eidsberg site (NISP=76)

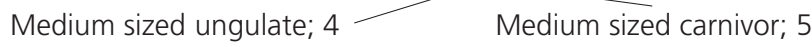

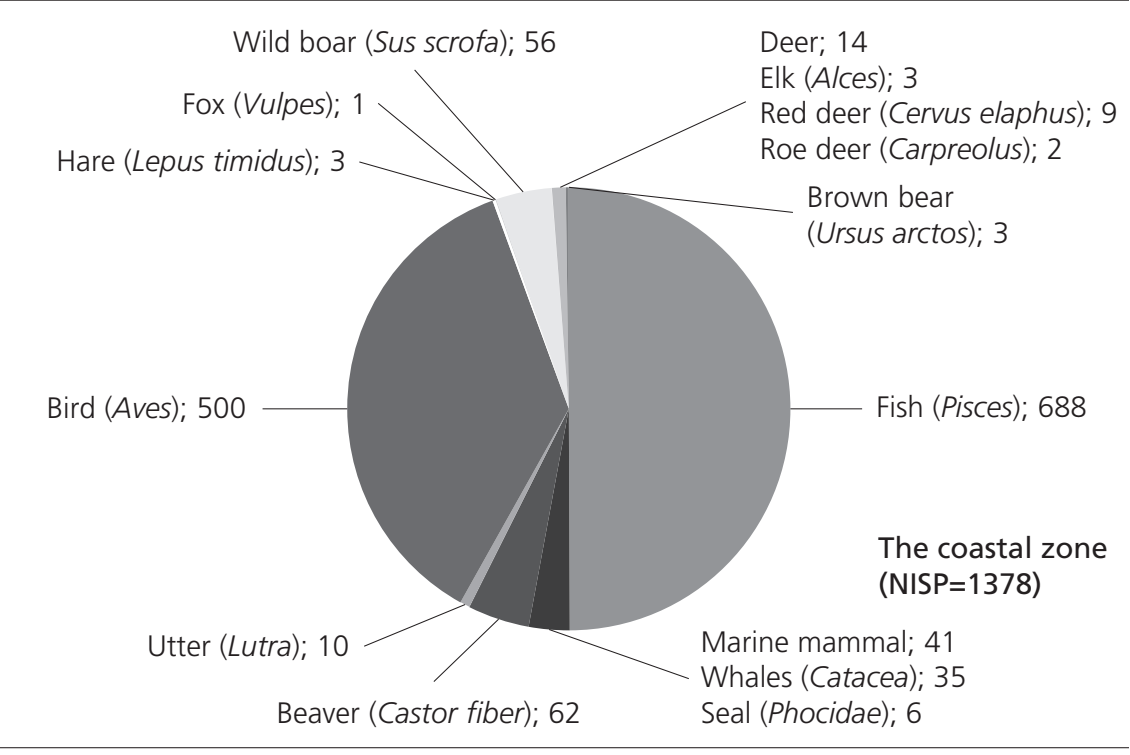

Brown bear (Ursus arctos); 2

Deer; 666

Elk (Alces); 665

Rein (Rangifer); 1

Wild boar (Sus scrofa); 6

Canine; 4

Hare (Lepus timidus); 7

Pine marten (Martes); 3

Bird (Aves); 4

Beaver (Castor fiber); 52

Fish (Pisces); 1432

The lowland zone

(NISP=2215) 
vian peninsula, the use of flint and quartz appears to be mutually exclusive during the period (e.g. Knutsson et al. 20I6), with the production of quartz inserts based on flakes and fragments, which is considered an adaptation to a quartz raw material that is harder to shape than flint. It is worth noting that the pieces attached to the resin from Eidsberg are not regular. In this way, the object is similar to inland technology using irregularly shaped inserts (Knutsson et al. 20I6). One can therefore look at the little composite piece as an exceptionally concrete example of a meeting between coast and inland, and from the flint dominance and the coastal location one can suspect that it was the coastal people who adapted the technology to the raw material situation at Mona Ridge.

The bone material from the Eidsberg settlement gives a different perspective on the question of the relationship between the settlers and the coastal areas. Some 1042 bone fragments with a total weight of $124 \mathrm{~g}$ have been analysed (Gustavsson 20I6; see also figure 9). Two bones of seal in addition to two other sea mammal bones from house pit 3 can be unambiguously linked to salt water. In Denmark, seal bone has been found at some inland localities from the Middle Mesolithic, and it has been assumed that they were brought inland by people who lived along the coast during part of the year (Blankholm 2008:I I9). Similarly the marine mammal bones at the Eidsberg site, along with the large amount of flint at the site, make it probable that there was a very close connection to the coastal zone. The easiest access from the coast was probably through the ravine landscape that lay to the south, a trip of at least $\mathrm{I} .3 \mathrm{~km}$ with an ascent of $85 \mathrm{~m}$ (see figure 2).

As already mentioned, is it not uncommon for members of forager societies to hunt, fish and collect more than $5 \mathrm{~km}$ away from their residential sites (Kelly 20I3:97). It would therefore have been possible for people living along the shores of the Glomma Fjord to make short-term visits to the Mona Ridge, although the journey, despite being short, may have posed challenges in rugged and dense forest terrain (see figure 2). People could thus have avoided building the shelters. An explanation of the fact that the buildings nevertheless were raised and inhabited as seasonal dwellings may be that those who visited the Mona Ridge were not settled close to the stretch of fjord closest to the Mona Ridge. The majority of the Middle Mesolithic settlements were situated further out in the coastal zone (see figure 2), where the marine landscape provided access to a wide and rich range of marine resources (e.g. Wigforss 1983:99; Lindblom I984; Andersson \& Wigforss 2004; Glørstad 20I0; Mansrud 20I4). If those who visited the Mona Ridge lived in the outer coastal zone, the distance may have been tens of kilometres. This would have made it impossible to make visits without overnight stays on the journey, thereby increasing the need to establish houses if they wanted to utilize the resources in the Eidsberg area. 


\section{THE EIDSBERG SITE AND RESOURCE UTILIZATION}

The Mesolithic population north and east of Skagerrak evidently sometimes chose to leave their ecological hotspots in favour of other areas. At times there was a desire to seek out particularly valuable resources, for example in connection with the extraction of minerals, big game hunting or salmon fishing. By establishing field camps in the moraine area, they would have had access to elk and other wildlife which preferred the pine forest inland (cf. Jonsson 1995:I50). Factors such as high hunting pressure on land-based big game in the limited and relatively densely populated land areas in the coastal zone may have helped to reinforce this pattern of extension in the Middle Mesolithic (Boethius 20I7:I53). Elk hunting probably played an important economic role, and at the same time it had a significant cultural role in the Middle and Late Mesolithic (Mjærum 20I8b; Fuglestvedt 20I8). The prestige of the game may also have been an important driving force for the move away from the coastal environment.

The purposeful production of slotted points indicates that big game hunting was an important task at Eidsberg. This interpretation is supported by the bone material from the site, even though the osteological record from Eidsberg is small and fragmented (see figure 9). Large cloven-hoofed animals, i.e. elk/deer, dominate the record. These are uncommon species in the osteological materials from Mesolithic sites in the region's coastal zone (see figure 9; see however Boethius 20I7:I5I), reinforcing the idea that elk must have been an important driving force behind the stays.

As already mentioned, there are numerous examples of extensive elk hunting further inland in Norway and Sweden, and in the Late Mesolithic and the Neolithic pit houses were in some cases constructed along streams, rivers and lakes in the region's elk-rich terrain (Fuglestvedt I992; Boaz I996; Lundberg 1997; Persson 20I3; Mjærum 20I8b). Those dwellings, along with the choice of locations, have similarities to the Eidsberg site, although the sites further inland were most likely also occupied during the winter (Boaz 1996; Lundberg 1997; Fretheim 2017:36).

The establishment of dwellings in the hinterland at Eidsberg is also comparable to Mullerup and other Middle Mesolithic 'big game' sites in southern Scandinavia (Grøn 1995; Blankholm 2008:1 I6-I I7; Leduc 20I3). It could thus be argued that some of these Danish inland sites are results of comparable movements by task groups between the coast and inland (cf. Fisher et al. 2007). A similar settlement pattern has been proposed for parts of western Norway, where task groups left their habitation sites on the outer coast for big game hunting in the inner fjords (Bergsvik et al. 20I6).

Big game hunting is an undertaking with a potentially large and culturally highly appreciated yield, but the risk of failure is high (Kelly 20I3:I34- 
I35). However, the consequences of a failed hunt may be limited if you base your stay on a wider range of resources (cf. Mjærum \& Mansrud in press). By establishing a field camp with houses, a more extended presence was made possible. This gave the opportunity to exploit natural riches that were difficult to transport over long distances (Kelly 20I3:96-98). The numerous hazelnut shells, quartz and bones from small mammals are traces of a varied resource base (figure 9), and the location of the houses on the border between the ravine landscape and the moraine must have been optimal to ensure access to a varied range of plants and prey. The risk of a failed hunt could also be reduced by cooperation and, not least, by dividing the catch - a basic aspect of most hunter-gatherer communities (Kelly 20I3:I37-165). Consequently, the fact that there were at least three separate households must have had great economic and social significance for those who made their way to the Mona Ridge.

\section{The shore settlement premise revisited}

Artefacts, the distribution of raw materials, cremated bones of forest animals, and pollen analyses previously provided clues suggesting people sought out areas far beyond the shore zone in Middle Mesolithic times in the hinterland north of Skagerrak. The Eidsberg site, however, is the region's first well-documented example of people purposefully establishing themselves beyond the shorelines to obtain desired natural resources.

Constructing and maintaining a dwelling was a large investment (Preston \& Cador 2018:326-327), not to be carried out without knowing the area in advance. The coastal people, even before the establishment of settlements, knew about the behaviour of the big game in the area, the available lithic raw material, and a host of other resources on the Mona Ridge and in the ravine landscape nearby.

This knowledge of the hinterland can hardly have been unique to the Mona Ridge. All around the world, resources are unevenly distributed, and numerous ethnographic accounts show that hunter-gatherers know what is going on in their extended environments (Kelly 20I3:6I). The coastal population north and east of the Skagerrak must also have had such an in-depth knowledge of other neighbouring inland areas - not just about the areas they chose to exploit, but also those they opted not to exploit.

How far inland from the shore this coastal hinterland stretched cannot be determined at present. To provide a detailed answer to this question, consideration must be given to local topography, to how people moved through the landscape, and not least to what cultural and economic forces motivated their stay further inland. In addition, a larger archaeological and 
archaeometric record is needed. However, the Eidsberg site proves that the Middle Mesolithic hunter-fisher-gatherer societies in the region were willing to establish field camps related to sought-after resources, and thereby utilized areas at a significant distance from the ecological hotspots in the coastal zone.

Although aquatic resources, waters and shores undoubtedly played a key role, the hinterland must be firmly included while discussing subsistence and settlement patterns among Mesolithic hunter-fisher-gatherers north and east of the Skagerrak coast. One should look for far more complex and diverse settlement patterns than can be expressed in a radial coastal-inland model where almost all activity is linked to ocean and freshwater shores (cf. Preston \& Cador 2018:326-327). Similarities between Eidsberg and sites further inland as well as in western Norway and in southern Scandinavia were pointed out above. These analogies, however, could also be turned the other way around. The main conclusions of this article, on semi-sedentary lifestyles and settlement patterns during the Mesolithic, should therefore have transfer value to other parts of the Scandinavian Peninsula and beyond.

\section{Acknowledgements}

This article was written within the International Research Network (IRN) 'PrehCOAST' at CNRS-INEE (holder: Grégor Marchand; co-holders: Pablo Arias, Valdis Bērziņ̃̌, Almut Schülke).

I would like to thank Hege Damlien and the reviewers for insightful comments, Hans-Martin Frydenberg Flåtten for language revision of parts of the text and Alan Crozier for proofreading. I would also like to show my gratitude to Mieko Matsumoto, Steinar Solheim and Espen Uleberg for contributing data to this article.

\section{References}

Amundsen, T. 2007. Lokaliteter fra steinbrukende tid: Åpne lokaliteter og kokegroper. In: Amundsen, T. (ed.). Elgfangst og bosetning $i$ Gråfjellområdet: Gråfjellprosjektet. Bind II, pp. 17-56. Oslo: Fornminneseksjonen, Kulturhistorisk museum.

Andersson, S. \& Wigforss, J. 2004. Senmesolitikum i Göteborgs- och Alingsåsområdena. Coast to Coast Books I2. Göteborg: Institutionen för arkeologi och antik historia. Uppsala universitet.

Berg-Hansen, I.M. 2009. Steinalderregistrering: Metodologi og forskningshistorie i Norge I900-2000 med en feltstudie fra Lista $i$ Vest-Agder. Varia 75. Oslo: Fornminneseksjonen, Kulturhistorisk museum.

Bergsvik, K.A. 2006. Ethnic Boundaries in Neolithic Norway. Oxford: Archaeopress. 
Bergsvik, K., Hufthammer, A.K. \& Ritchie, K. 20I6. The Emergence of Sedentism in Mesolithic Western Norway: A Case Study from the Rockshelters of Sævarhelleren and Olsteinhelleren by the Hardanger Fjord. In: Bjerck, H.B., Breivik, H.M., Fretheim, S.E., Piana, E.L., Skar, B., Tivoli, A.M. \& Zangrando, A.F.J. (eds). Marine Ventures: Archaeological Perspectives on Human-Sea Relations, pp. 33-52. Sheffield: Equinox Publishing.

Båtvik, J.I.I. 2000. Liste over høyere planter og fugl registret høsten 1987. In: Hardeng, G. (ed.). Naturfaglige undersøkelser av områder i Østfold (1970-99), pp. I2 I-I3I. Moss: Miljøvernavdelingen, Fylkesmannen i Østfold.

Binford, L. I980. Willow Smoke and Dog's Tails: Hunter Gatherer Settlement Systems and Archaeological Site Formation. American Antiquity. Vol. 45(I) pp. 4-20.

Berck, H.B. 2008. Norwegian Mesolithic Trends: A Review. In: Bailey, G. \& Spikins, P. (eds). Mesolithic Europe, pp. 6I-I06. Cambridge: Cambridge University Press.

Bjørgo, T. 1988. Registreringer som styrende fakorer i arkeologisk forskning. In: Indrelid, S., Kaland, S. \& Solberg, B. (eds). Festskrift til Anders Hagen, pp. I56-I66. Bergen: Historisk museum, Universitetet i Bergen.

Blankholm, H.P. 2008. Southern Scandinavia. In: Bailey, G. \& Spikins, P. (eds). Mesolithic Europe, pp. I07-I3I. Cambridge: Cambridge University Press.

Boaz, J. 1996. 'Skärvstensvaller” på Østlandet? Viking. Vol. 59 pp. 7-24.

Boaz, J. 1997. Steinalderundersøkelsene på Rødsmoen. Varia 4I. Oslo: Universitetets Oldsaksamling.

Boaz, J. I998. Hunter-Gatherer Site Variability Vhanging Patterns of Site Utilization in the Interior of Eastern Norway, between 8000 and 2500 B.P. Universitetets Oldsaksamlings skrifter. $\mathrm{Ny}$ rekke $\mathrm{Nr} 20$. Oslo: Universitetets Oldsaksamling.

Boethius, A. 2017. Signals of Sedentism: Faunal Exploitation as Evidence of a DelayedReturn Economy at Norje Sunnansund, an Early Mesolithic Site in South-Eastern Sweden. Quaternary Science Reviews. Vol. I62 pp. I45-I68.

Boethius, A. 2018. Huseby Klev and the Quest for Pioneer Subsistence Strategies: Diversification of a Marine Lifestyle. In: Persson, P., Riede, F., Skar, B., Breivik, H.M. \& Jonsson, L. (eds). Early Settlement in Northwestern Europe: Climate, Human Ecology, and Subsistence. Norwegian Pioneer-Network, pp. 99-I 28. Sheffield: Equinox Publishing.

Boethius, A. \& Ahlström, T. 20I8. Fish and Resilience among Early Holocene Foragers of Southern Scandinavia: A Fusion of Stable Isotopes and Zooarchaeology through Bayesian Mixing Modelling. Journal of Archaeological Science. Vol. 93 pp. 196-210.

Breivik, H.M., Fossum, G. \& Solheim, S. 20I8. Exploring Human Responses to Climatic Fluctuations and Environmental Diversity: Two Stories from Mesolithic Norway. Quaternary International. Vol. 465 pp. 258-275.

Britannica 1998. Hinterland, Encyclopædia Britannica, inc.

Brøgger, A.W. 1905. Øxer av Nøstvettypen: Bidrag til kundskaben om celdre norsk stenalder. Norges geologiske undersøkelse 42. Kristiania: Aschehoug.

Brøgger, W.C. 1905. Strandliniens beliggenhed under stenalderen i det sydøstlige Norge. Kristiania: Aschehoug.

Christensen, P. 20I4. Monaryggen og grusressursene - samfunnsnytte og ressursregnskap. Kommunedelplan for Slitu-Momarken med konsekvensutredninger. Sandvika: Asplan Viak.

Damlien, H. 20I4. Eastern Pioneers in Westermost Territories? Current Perspectives on Mesolithic Hunter-Gatherer Large-scale Interaction and Migration within Northern Eurasia. Quaternary International. Vol. 30 pp. I-I2. 
Damlien, H. 20I6. Between Tradition and Adaption: Long-term Trajectories of Lithic Tool-making in South Norway during the Postglacial Colonization and its Aftermath (c. 9500-7500 cal. BC). Stavanger: University of Stavanger, Faculty of Social Sciences, Museum of Archaeology.

Damlien, H. \& Solheim, S. 20I7. The Pioneer Settlement of Eastern Norway. In: Blankholm, H.P. (ed.). The Early Economy and Settlement in Northern Europe: Pioneering, Resource use, Coping with Change, pp. 335-367. Sheffield: Equinox Publishing.

Danielsen, A. I970. Pollen-analytical Late Quaternary Studies in the Ra District of Østfold, South-East Norway. Årbok for Universitetet i Bergen. Mat.-naturv. serie I4. Bergen: Norwegian universities press.

Eigeland, L. 2015. Maskinmennesket isteinalderen: Endring og kontinuitet isteinteknologi fram mot neolitiseringen av Øst-Norge. (Ph.d.). Universitetet i Oslo.

Ekstrand, S. 2013. Rapport fra arkeologisk utgravning. Skutvikåsen lok.3-5: Boplatser från äldre och yngre stenålder - med en depå från merovingertid. 227/IO \& I 2. Skien Telemark. Oslo: Fornminneseksjonen, Kulturhistorisk museum, Universitetet i Oslo. https://www.duo.uio.no/handle/I0852/55793. [Accessed I5 March 20I9].

Eriksson, G., Frei, K.M., Howcroft, R., Gummesson, S., Molin, F., Lidén, K., Frei, R. \& Hallgren, F. 20I7. Diet and Mobility among Mesolithic Hunter-Gatherers in Motala (Sweden): The Isotope Perspective. Journal of Archaeological Science: Reports. Vol. I7 pp. 904-9I8.

Eymundsson, C.S.R. 20I2. Rapport fra arkeologisk utgravning. Steinalderboplass og eldre jernaldersgrav. Nøstvet, I07/389, Ås, Akershus. Oslo: Fornminneseksjonen, Kulturhistorisk museum, Universitetet i Oslo. https://www.duo.uio.no/handle/Io852/53952. [Accessed I5 March 2019].

Eymundsson, C., Fossum, G., Koxvold, L.U., Mansrud, A. \& Mjærum, A. 2018. Axes in Transformation: A Bifocal View of Axe Technology in the Oslo Fjord Area, Norway, c. 9200-6000 cal BC. In: Knutsson, K., Knutsson, H., Apel, J. \& Glørstad, H. (eds). The Early Settlement of Northern Europe: Transmission of Knowledge and Culture, pp. 20I-229. Sheffield: Equinox Publishing.

Fischer, A. 2007. Coastal Fishing in Stone Age Denmark: Evidence from Below and Above the Presentsea Level and from Human Bones. In: Milner, N., Craig, O.E. \& Bailey, G. (eds). Shell Middens in Atlantic Europe, pp. 54-69. Oxford: Oxbow Books.

Fischer, A., Olsen, J., Richards, M., Heinemeier, J., Sveinbjörnsdottir, Á.E. \& Bennike, P. 2007. Coast-Inland Mobility and Diet in the Danish Mesolithic and Neolithic: Evidence from Stable Isotope Values of Humans and Dogs. Journal of Archaeological Science. Vol. 34 pp. 2I25-2I5O.

Fretheim, S.E. 20I7. Mesolithic Dwellings: An Empirical Approach to Past Trends and Present Interpretations in Norway. (P.hd.). Trondheim: Norwegian University of Science and Technology.

Fuglestvedt, I. I992. Svevollen: Et senmesolittisk boplassområde i det østnorske innland. (Magistergrad). Oslo: Universitetet i Oslo.

Fuglestvedt, I. 20I8. Rock Art and the Wild Mind, Visual Imagery in Mesolithic Northern Europe. New York: Routledge.

Glørstad, H. 2004. Kronologiske resultater fra Svinesundprosjektet. In: Glørstad, H. (ed.). Svinesundprosjektet Bind 4. Oppsummering av Svinesundprosjektet, pp. 2 I-46. Oslo: Universitetets kulturhistoriske Museer.

Glørstad, H. 20Iо. The Structure and History of the Late Mesolithic Societies in the Oslo fjord area 6300-3800 BC. Lindome: Bricoleur Press. 
Grøn, O. 1995. The Maglemose culture: The Reconstruction of the Social Organization of a Mesolithic Culture in Northern Europe. BAR International series 6I6. Oxford: Tempus Reparatum.

Grøn, O. 2003. Mesolithic Dwelling Places in South Scandinavia: Their Definition and Social Interpretation. Antiquity. Vol. 77(298) pp. 685-708.

Grøn, O. 20I 2. Our Grandfather Sent the Elk: Some Problems for Hunter-Gatherer Predictive Modelling. Quartär. Vol. 59 pp. I75-188.

Gundersen, J. 20I3. Verken fjord eller fjell - steinalderen i det kystnære innlandet: Gamle og nye funn fra Notodden i Telemark. Viking. Vol. 76 pp. 35-62.

Gustavsson, R. 2016. Osteologisk analys. Brända ben från mesolitiska hyddorvid Eidsberg fengsel, Østereng 5I/6, Eidsbergs kommun, Østfold, Norge. Kulturhistorisktmuseum, Oslo universitet. Uppsala: SAU (Societas Archaeologica Upsaliensis).

Hernek, R. 2005. Nytt ljus på Sandarnakulturen: Om en boplats från äldre stenåldern $i$ Bohuslän. Gotarc Series B. Gothenburg Archaeological Thesis. Vol. 38. Coast to Coast book. Vol. I4. Göteborg: Göteborgs Universitet, Institutionen för arkeologi.

Høeg, H.I. I997. Pollenanalytiske undersøkelser på Øvre Romerike: Ullensaker og Nannestad, Akershus fylke. Gardermoprosjektet. Varia 46. Oslo: Universitetets Oldsaksamling.

Høeg, H.I., Henningsmoen, K.E. \& Sørensen, R. 20I 8. Innvandring og spredning av vanlige skogstrær på Sørøstlandet. Blyttia. Vol. 76(3) pp. I89-203.

Hufthammer, A.K. 2006. The Vertebrate Fauna of Eastern Norway: From the Ice Age to the Middle Ages. In: Glørstad, H., Skar, B. \& Skre, D. (eds). Historien i forhistorien: Festskrift til Einar Østmo på 60-årsdagen, pp. 19I-202. Oslo: Kulturhistorisk Museum, Universitetet i Oslo.

Hufthammer, A.K. \& Hodgetts, L. I997. Appendix r: Faunal Material from the Stone Age Excevations at Rødsmo. In: Boaz, J. (ed.). Steinalderundersøkelsene på Rødsmoen, pp. I49-I 58. Oslo: Universitetets Oldsaksamling.

Indrelid, S. 1994. Fangstfolk og bønder i fjellet: Bidrag til Hardangerviddas førhistorie 8500-2500 år for nåtid. Universitetets Oldsaksamlings Skrifter. Ny rekke I7. Oslo: Universitetets Oldsaksamling.

Inizan, M.-L., Ballinger, M.R., Roche, H. \& Tixier, J. 1999. Technology and Terminology of Knapped Stone. Préhistorie de la Pierre Taillée 5. Nanterre: Cercle de recherches et d'études préhistoriques.

Jaksland, L. 200I. Vinterbrolokalitetene en kronologisk sekvens fra mellom- og senmesolitikum $i \AA ̊ 丿$ s, Akershus. Varia 52. Oslo: Universitetets kulturhistoriske museer.

Jonsson, L. I995. Vertebrate Fauna during the Mesolithic on the Swedish West Coast. In: Fischer, A. (ed.). Man and Sea in the Mesolithic: Coastal Settlement above and below Present Sea Level. Proceedings of the Onternational Symposium, Kalundborg, Denmark 1993, pp. I47-I60. Oxford: Oxbow books.

Kelly, R.L. 20I3. The Lifeways of Hunter-Gatherers: The Foraging Spectrum. Cambridge: Cambridge University Press.

Kindgren, H. I99I. Kambrisk flinta och etniska grupper i Västergötlands senmesolitikum. In: Browall, H., Persson, P. \& Sjögren, K.-G. (eds). Västsvenska stenåldersstudier, pp. 33-70. Göteborg: Göteborgs universitet, Institutionen för arkeologi.

Knutsson, H., Knutsson, K., Molin, F. \& Zetterlund, P. 20I6. From Flint to Quartz: Organization of Lithic Technology in Relation to Raw Material availability during the Pioneer Process of Scandinavia. Quaternary International. Vol. 424 pp. 32-57. 
Leduc, C. 2013. Ungulates Exploitation for Subsistence and Raw Material, during the Maglemose Culture in Denmark: The Example of Mullerup Site (Sarauw's Island) in Sjælland. Danish Journal of Archaeology. Vol. I(I) pp. 62-8I.

Lidén, K., Eriksson, G., Nordqvist, B., Götherström, A. \& Bendixen, E. 2004. 'The Wet and the Wild followed by the Dry and the Tame' - or did they Occur at the Same Time? Diet in Mesolithic-Neolithic Southern Sweden. Antiquity. Vol. 78(299) pp. 23-33.

Lindblom, I. I984. Former for økologisk tilpassning i mesolitikum. Universitetets Oldsaksamling Årbok. Vol. 1982/1983 pp. 87-IO2.

Lundberg, A. I997. Vinterbyar: Ett bandsambälles territorier i Norrlands inland, 45002500 f.Kr. Umeå: Universitetet i Umeå.

Macphail, R.I. \& Linderholm, J. 20I7. Eidsbergfengsel, Eidsberg kommune, Norway: Soil Micromorphology, Chemistry and Magnetic Susceptibility Studies. Umeå: Institute of Archaeology, University College London and Environmental Archaeology Laboratory, Umeå.

Madsen, A.P., Müller, S., Neergaard, C., Petersen, C.G.J., Rostrup, E., Steenstrup, K.J.V. $\&$ Winge, H. I900. Affaldsdynger fra Stenalderen $i$ Danmark undersøgte for Nationalmuseet. Paris: A.A. Hachette.

Mansrud, A. 20I4. Mobil eller bofast? Erverv, landskap og mobilitet i mellommesolittiske kystsamfunn i Øst-Norge (8300-6300 f.Kr.). Norsk Maritimt Museums Årbok. Vol. 2013 pp. 67-I08.

Mansrud, A. \& Persson, P. 2018. Waterworld: Enviroment, Animal Exploitation and Fishhook Technology in the North Eastern Skagerrak Area during the Early and Midddle Mesolithic (9500-6300 BC). In: Persson, P., Riede, F., Skar, B., Breivik, H.M. \& Jonsson, L. (eds). Early Settlement in Northwestern Europe: Climate, Human Ecology, and Subsistence. Norwegian Pioneer-Network, pp. I29-I66. Sheffield: Equinox Publishing.

Melvold, S. 20I2. Rapport fra arkeologisk utgravning. Boplassfunn: Eldre steinalderbronsealder. Eidsvold Verk 97/I, Eidsvoll, Akershus. E6-prosjektet Dal-Minnesund. Delrapport I av 6 - Andelva. Oslo: Fornminneseksjonen, Kulturhistorisk museum, Universitetet i Oslo. https://www.duo.uio.no/handle/Io852/5603 I. [Accessed I5 March 20I9].

Melvold, S. \& Eigeland, L. 20I 4. Langangen Vestgård I: En boplass fra siste del av mellommesolitikum med trinnøksproduksjon og strukturer. In: Melvold, S. \& Persson, P. (eds). Vestfoldbaneprosjektet. Arkeologiske undersøkelser i forbindelse med ny jernbane mellom Larvik og Porsgrunn. Bind I. Tidlig-og mellommesolittiske lokaliteter $i$ Vestfold og Telemark, pp. 239-276. Krisitansand: Portal forlag.

Mikkelsen, E. 1989. Fra jeger til bonde: Utviklingen av jordbrukssamfunn i Telemark $i$ steinalder og bronsealder. Universitetets Oldsaksamlings skrifter. Ny rekke II. Oslo: Universitetets Oldsaksamling.

Mikkelsen, E., Ballin, T. \& Hufthammer, A.K. I999. Tørkop: A Boreal Settlement in SouthEastern Norway. Acta Archaeologica. Vol. 70 pp. $25-57$.

Mikkelsen, E. \& Høeg, H. 1977. Hakker av elg- og hjortehorn funnet i Norge. Universitetets Oldsaksamling Årbok. Vol. 1975-1976 pp. I I-28.

Mjærum, A. 20I8a. Rapportfra arkeologisk utgravning. Mellommesolittiske groptufter, bosetningsspor fra bronse- og jernalder og kullgrop fra nyere tid. Eidsberg fengsel, Østereng, 5I/6, Eidsberg, Østfold. Oslo: Arkeologisk seksjon, Kulturhistorisk museum, Universitetet i Oslo. https://www.duo.uio.no/handle/I0852/60027. [Accessed I5 March 2019].

Mjærum, A. 20I 8b. Hunting Elk at the Foot of the Mountains: Remains from 8000 Years of Foraging at the Edge of the Hardangervidda Plateau in Southern Norway. In: Persson, P., 
Riede, F., Skar, B., Breivik, H.M. \& Jonsson, L. (eds). Early Settlement in Northwestern Europe: Climate, Human Ecology, and Subsistence. Norwegian Pioneer-Network, pp. I67-195. Sheffield: Equinox Publishing.

Mjærum, A. 2019. Rapport fra arkeologisk utgravning. Havsjødalen, et boplassområde fra nøstvetfasen. Dal øvre, 46/4. Frogn kommune, Akershus. Oslo: Arkeologisk seksjon, Kulturhistorisk museum, Universitetet i Oslo.

Mjærum, A. \& Mansrud, A. In press. Resource Management in Late Mesolithic Eastern Norway? New Evidence for Fishing in the Coastal, Interior and Mountain Areas and its Long-Term Societal Implications. In: Schülke, A. (ed.). The Coastal Landscapes of the Mesolithic. Abingdon: Routledge.

Munthe, H. I9I0. Studies in the Late-Quaternary History of Southern Sweden. Förhandlingar. Vol. 32(5) pp. II97-I293.

Nordqvist, B. I997. Mesolitiska grönstensyxor i Västsverige. In: Larsson, M. \& Olsson, E. (eds). Regionalt och interregionalt: Stenåldersundersökningar i Syd-och Mellansverige, pp. 64-70. Stockholm: Riksantikvariämbetet.

Nordqvist, B. 2000. Coastal Adaptations in the Mesolitic [i.e. Mesolithic]: A Study of Coastal Sites with Organic Remains from the Boreal and Atlantic periods in Western Sweden. Göteborg: Göteborg University.

Nyborg, A. 2009. Jordsmonnatlas for Norge: Beskrivelse og klassifikasjon av jordsmonnet på dyrka mark $i$ Østfold. Ås: Norsk institutt for skog og landskap.

Nyland, A.J. 2016. Humans in Motion and Places of Essence: Variations in Rock Procurement Practices in the Stone, Bronze and Early Iron Ages, in Southern Norway. Oslo: University of Oslo.

Olsen, D.E.F. 20I3. Hovland I: En boplass fra mellommesolitikum. In: Solheim, S. \& Damlien, H. (eds). EI8 Bommestad-Sky. Undersøkelser av lokaliteter fra mellommesolitikum, Larvik kommune, Vestfold fylke, pp. I7 I-I97. Kristiansand: Portal Forlag.

Olsen, A.B. I992. Kotedalen: En boplass gjennom 5000 år. Bind I. Fangstbosetning og tidlig jordbruk i vestnorsk steinalder: Nye funn og nye perspektiver. Bergen: Universitetet i Bergen, Historisk museum.

Pelegrin, J. 1990. Prehistoric Lithic Technology: Some Aspects of Research. Archaeological Review from Cambridge. Vol. 9(I) pp. II6-I25.

Persson, P. 20I3. Changes during the Late Mesolithic in the Central Scandinavian Inland. In: Bergerbrant, S. \& Sabatini, S. (eds). Counterpoint: Essays in archaeology and heritage in honour of Professor Kristian Kristiansen, pp. 29-34. Oxford: Archaeopress.

Persson, P. 20I4. Prestemoen I. En plats med ben från mellanmesolitikum. In: Melvold, S. \& Persson, P. (eds). Vestfoldbaneprosjektet. Arkeologiske undersøkelser i forbindelse med ny jernbane mellom Larvik og Porsgrunn. Bind I. Tidlig- og mellommesolittiske lokaliteter $i$ Vestfold og Telemark, pp. 202-227. Krisitansand: Portal forlag.

Persson, P. 2018. Earliest Settlement in Middle Scandinavian Inland: A Discussion about Joel Boaz's Pioneers in the Mesolithic. In: Persson, P., Riede, F., Skar, B., Breivik, H. M. \& Jonsson, L. (eds). Early Settlement in Northwestern Europe: Climate, Human Ecology, and Subsistence. Norwegian Pioneer-Network, pp. I97-2 I7. Sheffield: Equinox Publishing.

Preston, P.R. \& Kador, T. 2018. Approaches to Interpreting Mesolithic Mobility and Settlement in Britain and Ireland. Journal of World Prehistory, Vol. $3 \mathrm{I}(3)$ pp. $32 \mathrm{I}-345$.

Puschmann, O. 2005. Nasjonalt referansesystem for landskap: Beskrivelse av Norges 45 landskapsregioner. https://www.nibio.no/tema/landskap/landskapskart/nasjonaltreferansesystem-for-landskap/landskapsregioner. [Accessed I5 March 20I9]. 
Rekdal, Y. 20I8. Vegatasjonstyper [online]. NIBIO. https://www.nibio.no/tema/landskap/ vegetasjonskart/vegetasjonstyper. [Accessed 28 April 20I8].

Reitan, G. 20I6. Mesolittisk kronologi i Sørøst-Norge: Et forlslag til justering. Viking. Vol. 79 pp. 23-5I.

Sarauw, G. \& Alin, J. I923. Götaälvsområdets fornminnen. Götaälvsområdets fornminnen 3. Göteborg: Skrifter utgivna till Göteborgs stads trehundraårsjubileum genom jubileumsutställningens publikationskommitté.

Schmitt, L. 20I5. Early Colonization, Glacial Melt Water, and Island Mass Effect in the Archipelago of Western Sweden: A Case History. Oxford Journal of Archaeology. Vol. 34(2) pp. IO9-II7.

Selsing, L. 20I0. Mennesker og natur i fjellet i Sør-Norge etter siste istid med hovedvekt på mesolitikum. Stavanger: Arkeologisk museum.

Skar, B., Lidén, K., Eriksson, G. \& Sellevold, B. 20I6. A Submerged Mesolithic Grave Site Reveals Remains of the First Norwegian Seal Hunters. In: Bjerck, H.B., Breivik, H.M., Fretheim, S.E., Piana, E.L., Skar, B., Tivoli, A.M. \& Zangrando, A.F.J. (eds). Marine Ventures: Archaeological Perspectives on Human-Sea Relations, pp. 225-239. Sheffield: Equinox Publishing.

Snoeck, C., Brock, F. \& Schulting, R.J. 20I4. Carbon Exchanges between Bone Apatite and Fuels during Cremation: Impact on Radiocarbon Dates. Radiocarbon, Vol. 56(2) pp. 603-617.

Solheim, S. 2010. Der øst møter vest: Til høgfjellets forhistorie. Viking. Vol. 73 pp. 29-48.

Solheim, S. 20I2. Lokal praksis og fremmed opphav: Arbeidsdeling, sosiale relasjoner og differensiering i østnorsk tidligneolitikum. (Ph.d.). Oslo: Universitetet i Oslo.

Solheim, S. 20I7. EI8 Rugtvedt-Dørdal. Arkeologiske undersøkelser av lokaliteter fra msteinalder og jernalder $i$ Bamble kommune, Telemark fylke. Kristiansand: Portal Forlag.

Solheim, S. \& Damlien, H. 20I3. EI8 Bommestad-Sky. Undersøkelser av lokaliteter fra mellommesolitikum, Larvik kommune, Vestfold fylke. Kristiansand: Portal Forlag.

Solheim, S. \& Olsen, D.E.F. 20I3. Hovland 3: Mellommesolittisk boplass med hyttetuft. In: Solheim, S. \& Damlien, H. (eds). EI 8 Bommestad-Sky. Undersøkelser av lokaliteter fra mellommesolitikum, Larvik kommune, Vestfold fylke, pp. 198-235. Kristiansand: Portal Forlag.

Solheim, S. \& Persson, P. 20I6. Marine Adaptation in the Middle Mesolithic of SouthEastern Norway. In: Bjerck, H.B., Breivik, H.M., Fretheim, S.E., Piana, E.L., Skar, B., Tivoli, A.M. \& Zangrando, A.F. (eds). Marine Ventures: Archaeological Perspectives on Human-Sea Relations, pp. 26I-276. Sheffield: Equinox Publishing.

Solheim, S. \& Persson, P. 2018. Early and Mid-Holocene Coastal Settlement and Demography in Southeastern Norway: Comparing Distribution of Radiocarbon Dates and Shoreline-Dated Sites, 8500-2000 cal. BCE. Journal of Archaeological Science: Reports. Vol. I9 pp. 334-343.

Sørensen, M. 2006. Teknologiske traditioner i Maglemosekulturen: En diakron analyse af maglemosekulturens flækkeindustri. In: Eriksen, B.V. (ed.). Stenalderstudier: Tidligt mesolitiske jogere og salmere i Sydskandinavien, pp. 19-75. Højbjerg: Jysk Arkeologisk Selskab.

Sørensen, R. 2006. Fortidsfolket kommer. In: Løvland, B. (ed.). Sørmarka, pp. 44-46. Oslo: Andresen \& Butenschøn.

Stene, K. 20I0. Steinalderundersøkelser ved Rena elv. Gråfjellprosjektet. Bind III. Varia 76. Oslo: Kulturhistorisk museum, Fornminneseksjonen. 
Stene, K., Persson, P., Damlien, H. \& Melvold, S. 20Io. Lokaliteter fra steinbrukende tid ved Rena elv. In: Stene, K. (ed.). Steinalderundersøkelser ved Rena elv: Gråfjellprosjektet. Bind III, pp. 459-520. Oslo: Kulturhistorisk museum, Fornminneseksjonen.

Unimus 20I8. MUSIT \& Making Waves. www.unimus.no/arkeologi. [Accessed 27 April 20I8].

Wieckowska-Lüth, M., Solheim, S., Schülke, A. \& Kirleis, W. 20ı8. Towards a Refined Understanding of the use of Coastal Zones in the Mesolithic: New Investigations on Human-Environment Interactions in Telemark, Southeastern Norway. Journal of Archaeological Science: Reports. Vol. I7 pp. 839-85I.

Wigforss, J. I983. Arkeologisk undersökning. In: Wigforss, J., Lepiksaar, J., Olsson, I.U. and Påsse, T. (eds). Bua Västergård: En 8000 år gammal kustboplats, pp. 9-ı I . Göteborg: Göteborgs arkeologiska museum.

Winther, T. \& Persson, P. 20I6. Rapport fra arkeologisk utgravning. Delrapport I: Osneset. Undersøkelse av steinalderboplass med flere aktivitetsområder. Osneset gård 73/37 og Osneset kirkegård 73/I27, Åmot, Hedemark. Oslo: Arkeologisk seksjon, Kulturhistorisk museum, Universitetet i Oslo. 